\title{
Hubungan konseling antenatal dan pemilihan kontrasepsi ibu hamil primigravida
}

\author{
Riawanti ${ }^{1}$ Pusparini $^{2}$
}

\begin{abstract}
ABSTRAK
\section{LATAR BELAKANG}

Kebutuhan akan kontrasepsi pada masa setelah persalinan perlu direncanakan sejak masa kehamilan termasuk juga dalam memilih kontrasepsi yang tepat sesuai kondisi dan kebutuhan. Informasi mengenai kontrasepsi perlu diberikan melalui konseling selama pelayanan antenatal. Konseling antenatal merupakan bentuk dari konseling yang membantu dalam pemilihan kontrasepsi yang paling sesuai dan meningkatkan pengetahuan ibu hamil mengenai risiko, keuntungan, dan efek samping kontrasepsi. Tujuan penelitian ini adalah untuk mengetahui hubungan antara konseling antenatal dan pemilihan kontrasepsi ibu hamil primigravida.
\end{abstract}

\section{METODE}

Penelitian ini menggunakan metode penelitian observasional analitik dengan pendekatan cross-sectional. Delapan puluh sembilan (89) reponden primigravida yang memenuhi kriteria inklusi dan eksklusi dan bersedia berpartisipasi diikutsertakan sebagai sampel penelitian. Penelitian dilakukan pada bulan September sampai Desember 2017 di Puskesmas Pasekan Kabupaten Indramayu, Jawa Barat. Pengambilan data dilakukan dengan pengisian kuesioner, meliputi karakteristik demografi, konseling antenatal, pengetahuan, sikap, pemilihan alat kontrasepsi setelah persalinan. Pengisian kuesioner tersebut didampingi langsung oleh peneliti sehingga seluruh kuesioner terisi lengkap. Data dianalisis dengan menggunakan uji Fisher exact dengan tingkat kemaknaan $\mathrm{p}<0.05$.

\section{HASIL}

Pengetahuan ibu primigravida yang termasuk kategori baik sebanyak 22 orang $(24.7 \%)$, kategori cukup sebanyak 63 orang $(70.8 \%)$, dan kategori kurang sebanyak 4 orang (4.5\%). Dari sikap, terdapat 76 orang $(85.4 \%)$ kategori baik, kategori cukup sebanyak 12 orang (13.5\%), dan kategori kurang sebanyak 1 orang (1.1\%). Hasil uji Fisher antara konseling antenatal dan pemilihan kontrasepsi menunjukkan terdapat hubungan yang bermakna dengan nilai $\mathrm{p}=0.02$.

\section{KESIMPULAN}

Terdapat hubungan yang bermakna antara konseling antenatal dan pemilihan kontrasepsi pada ibu hamil primigravida.

Kata kunci : konseling, antenatal care, primigravida, kontrasepsi

\author{
${ }^{1}$ Program Studi Kedokteran, \\ Fakultas Kedokteran, \\ Universitas Trisakti \\ ${ }^{2}$ Departemen Patologi Klinik, \\ Fakultas Kedokteran, \\ Universitas Trisakti
}

\section{Korespondensi:}

Pusparini

Departemen Patologi Klinik,

Fakultas Kedokteran,

Universitas Trisakti

Email: pusparini@trisakti.ac.id

J Biomedika Kesehat 2018;1(2):119-

125

DOI: $10.18051 /$ JBiomedKes.2018.

v1.119-125

pISSN: 2621-539X / eISSN: 2621-5470

Artikel akses terbuka (open access) ini didistribusikan di bawah lisensi Creative Commons Attribution 4.0 International (CC-BY 4.0) 


\section{ABSTRACT}

\section{Relationship between antenatal counseling and choice of contraception in primigravida}

\section{BACKGROUND}

Recent data showed a significant increase in the prevalence of depression among adolescent compared to children The need of contraceptive during post-natal period must be planned since pregnancy period as well as choosing the right contraceptive according to conditions and needs. Informations about contraceptive need to be given through counselings during antenatal care. Antenatal counselings are a form of counseling which helps in choosing the most suitable contraceptive and improving pregnant women's knowledges about risks, benefits, and side effects of contraceptives. The aim of this study was to investigate the relationship between antenatal counseling and contraceptive choosing in primigravida.

\section{METHODS}

This research utilized an analytic observational research method through cross-sectional approach with samples of pregnant women categorized as primigravida. A total samples of 89 respondents who were primigravida pregnant women attending Pasekan's community health center in Indramayu regency, West Java. This research was conducted from September to December 2017. Data collection by interview through questionnaire including demography characteristic, antenatal counseling, knowledge, behaviour and contraceptive choice post partum. Data were analyzed using Fisher exact test through SPSS program with significance level of $\mathrm{p}<0.05$.

\section{RESULT}

The results from this research showed that primigravida women's knowledge categorized as good were 22 people $(24.7 \%)$, categorized as enough were 63 people $(70.8 \%)$, and categorized as less were 4 people $(4.5 \%)$. Reviewed of behavior, there were 76 people $(85.4 \%)$ categorized as good, respondents with enough behavior were 12 people $(13.5 \%)$, and respondents categorized as less behavior was 1 person $(1.1 \%)$. Fisher exact test between antenatal counseling and contraceptive selection showed significantly with p-value of 0.020 .

\section{CONCLUSION}

There was a relation between antenatal counseling and contraceptive selection on the primigravida pregnant women.

Keywords : counseling, antenatal care, primigravida, contraceptives

\section{PENDAHULUAN}

Indonesia merupakan negara dengan jumlah penduduk terbesar ke empat di dunia. Berdasarkan data dari Pusat Data dan Informasi Kementerian Kesehatan RI tahun 2015, jumlah penduduk pada tahun 2015 sebesar 255.461.686 jiwa, yang terdiri atas 128.366.718 jiwa penduduk laki-laki dan 127.094.968 jiwa penduduk perempuan. ${ }^{(1)}$

Berdasarkan data dari Survei Dasar Kesehatan Indonesia (SDKI) 2012 menunjukkan bahwa hampir 50 persen dari wanita menginginkan memiliki anak dan sebanyak 50 persen dari wanita kawin menyatakan mereka tidak ingin mempunyai anak lagi atau telah disterilisasi. ${ }^{(2)}$ Presentase untuk memiliki anak juga dipengaruhi oleh lingkungan tempat tinggal. Wanita dan pria di daerah perkotaan menginginkan jumlah anak lebih sedikit, dibandingkan wanita dan pria di pedesaan. Kondisi ini mungkin berkaitan dengan pola pikir pasangan dengan status ekonomi yang lebih tinggi, yaitu anak merupakan tanggung jawab bukan sebagai aset untuk membantu ekonomi. ${ }^{(3)}$ Salah satu cara mengatasi masalah ini adalah dengan penggunaan Keluarga Berencana (KB). Permasalahan yang terjadi adalah banyak para ibu atau bapak yang tidak mengetahui tentang metode kontrasepsi setelah persalinan. ${ }^{(4)}$

Guna mengatasi permasalahan di atas maka diperlukan suatu upaya untuk memberikan Konseling atau Informasi dan Edukasi (KIE) pada setiap calon akseptor KB sebelum memutuskan pilihan metode kontrasepsi. ${ }^{(4)}$ Penelitian Akman et al juga menyebutkan bahwa konseling KB dapat meningkatkan penggunan kontrasepsi pada periode postpartum. ${ }^{(5)}$ Studi mengenai penggunaan kontrasepsi setelah persalinan pada wanita di Indonesia masih terbatas. Khususnya pada ibu primigravida (PG). Primigravida adalah kelompok berisiko tinggi karena ini adalah awal dari sebuah kehidupan baru bagi seorang wanita, hal ini dianggap sebagai kelompok penting yang membutuhkan bantuan reguler dalam hal perawatan antenatal, natal dan post natal, dan ini akan membantu 
pasien ini selama kehamilan, persalinan dan masa nifas. ${ }^{(6)}$

Konseling antenatal memberikan dampak yang signifikan dalam memilih kontrasepsi yang paling sesuai dan meningkatkan pengetahuan ibu hamil mengenai risiko, keuntungan, dan efek samping kontrasepsi. ${ }^{(7)}$ Tujuan penelitian ini adalah untuk mengetahui hubungan antara konseling antenatal dan pemilihan konstrasepsi ibu hamil primigravida.

\section{METODE}

Penelitian ini menggunakan desain penelitian cross-sectional. Penelitian dilakukan pada bulan September sampai dengan Desember 2017 di Puskesmas Pasekan, Indramayu Jawa Barat. Kriteria inklusi yaitu ibu hamil primigravida trimester II dan III, usia 17-35 tahun, tercatat di buku register kohort dan bersedia berpartisipasi dalam penelitian. Kriteria eksklusi pada penelitian ini adalah Ibu hamil yang mempunyai penyakit penyerta seperti preeklamsia, HIV, rubella, infeksi toxoplasma. Pengambilan sampel dilakukan dengan metode consecutive sampling. Besar sampel yang digunakan dalam penelitian ini sesuai dengan penghitungan rumus di bawah ini:

$$
\underline{\mathrm{n}=(\mathrm{Z} \alpha)^{2}} \frac{\mathrm{xp \times q}}{\mathrm{d}^{2}}
$$

Peneliti memberikan konseling satu persatu kepada responden yang memenuhi kriteria inklusi dan eksklusi dan telah menandatangani informed consent. Delapan puluh sembilan (89) responden mengisi kuesioner sendiri yang terdiri dari karakteristik demografi, konseling antenatal, pengetahuan, sikap, pemilihan alat kontrasepsi pasca salin. Pengisian kuesioner tersebut didampingi langsung oleh peneliti sehingga seluruh kuesioner terisi lengkap. Data dianalisis dengan uji Fisher exact dengan tingkat kemaknaan sebesar 0,05. Penelitian ini telah lolos kaji etik FK Universitas Trisakti dengan No.35/KER-FK/VII/2017.

\section{HASIL}

Tabel 1. Karakteristik subjek penelitian

\begin{tabular}{lcc}
\hline Variabel & $\begin{array}{c}\text { Frekuensi } \\
(\mathbf{n})\end{array}$ & $\begin{array}{c}\text { Persentase } \\
(\%)\end{array}$ \\
\hline Usia & 31 & 34.8 \\
$<20$ tahun & 58 & 65.2 \\
20-35 tahun & & \\
Pendidikan & 24 & 27.0 \\
SD & 30 & 33.7 \\
SMP & 30 & 33.7 \\
SMA & 5 & 5.6 \\
Sarjana (S1) & & \\
Status Pekerjaan & 16 & 18.0 \\
Bekerja & 73 & 82.1 \\
Tidak Bekerja & & \\
Tingkat Pendapatan & & 83.1 \\
< UMK & 74 & 16.9 \\
> UMK & 15 & \\
\hline
\end{tabular}

Sebanyak 89 responden primigravida ikut serta dalam penelitian ini. Tabel 1 memperlihatkan bahwa responden didominasi oleh ibu hamil usia antara 20-35 tahun (65.2\%). Terdapat 30 responden $(33.7 \%)$ dengan pendidikan SMP dan SMA. Hampir seluruh responden tidak bekerja yaitu sebanyak 73 responden $(82.1 \%)$. Tingkat pendapatan responden didominasi oleh responden yang mempunyai pendapatan kurang dari UMK sebanyak 74 responden $(83.1 \%)$.

Tabel 2. Distribusi subjek berdasarkan konseling, sikap dan pilihan kontrasepsi

\begin{tabular}{lcc}
\hline Variabel & $\begin{array}{c}\text { Frekuensi } \\
\text { (n) }\end{array}$ & $\begin{array}{c}\text { Persentase } \\
\text { (\%) }\end{array}$ \\
Riwayat Konseling & 71 & 79.8 \\
Baru pertama kali & & \\
konseling & 18 & 20.2 \\
> 1 kali konseling & & \\
Pengetahuan & 22 & 24.7 \\
Baik & 63 & 70.8 \\
Cukup & 4 & 4.5 \\
Kurang & & \\
Sikap & 76 & 85.4 \\
Baik & 12 & 13.5 \\
Cukup & 1 & 1.1 \\
Kurang & & \\
Pilihan Kontrasepsi & 70 & 78.7 \\
Ya & 19 & 21.3 \\
Tidak & & \\
\hline
\end{tabular}

Berdasarkan Tabel 2 terlihat bahwa sebagian besar responden baru pertama kali konseling sebanyak 71 responden (79.8\%). Sebagian besar responden juga mempunyai pengetahuan yang cukup sebanyak 63 responden $(70.8 \%)$. Hampir keseluruhan responden mempunyai sikap yang baik 
Tabel 3. Hubungan konseling dengan pilihan kontrasepsi

\begin{tabular}{lcccc} 
& \multicolumn{1}{c}{ Pilihan Kontrasepsi } & & Total & p-value \\
\cline { 2 - 4 } & $\begin{array}{c}\text { Ya } \\
\mathbf{n}(\mathbf{\%})\end{array}$ & $\begin{array}{c}\text { Tidak } \\
\mathbf{n}(\mathbf{\%})\end{array}$ & & \\
\hline Konseling Antenatal 1x & $60(84.5)$ & $11(15.5)$ & 71 & $0.020^{*}$ \\
Konseling Antenatal $>1 \mathrm{x}$ & $10(55.6)$ & $8(44.4)$ & 18 & \\
\hline *) Fisher's exact test, nilai $\mathrm{p}<0.05$ & & &
\end{tabular}

sebanyak 76 responden $(85.4 \%)$. Terdapat 70 responden $(78.7 \%)$ yang menggunakan kontrasepsi.

Dari Tabel 3 dapat dilihat bahwa variabel pilihan kontrasepsi mempunyai jumlah responden paling tinggi pada kategori "ya" sebanyak 60 orang $(84.5 \%)$ dengan riwayat konseling baru pertama kali. Hasil uji Fisher menunjukkan terdapat hubungan yang bermakna antara riwayat konseling dan pemilihan kontrasepsi dengan nilai $\mathrm{p}=0.020$.

Tabel 4 memperlihatkan responden yang melakukan konseling antenatal pertama kali mempunyai pengetahuan yang cukup sehingga mereka mau menggunakan kontrasepsi sebanyak 46 responden $(88.5 \%)$. Responden yang melakukan antenatal lebih dari satu kali juga mempunyai pengetahuan yang cukup sehingga mereka mau menggunakan kontrasepsi sebanyak 6 orang $(54.5 \%)$. Responden yang melakukan konseling antenatal pertama kali didominasi oleh responden yang mempunyai sikap baik 54 responden (84.4\%). Untuk responden yang melakukan konseling lebih dari satu kali mempunyai sikap baik namun responden ada yang memilih mau menggunakan kontrasepsi dan tidak menggunakan kontrasepsi masing masing sebanyak 6 responden $(50 \%)$.

\section{PEMBAHASAN}

Hasil penelitian pada Tabel 1 memperlihatkan sebagian besar responden berusia 20-35 tahun (65.2\%), hal ini disebabkan rentang usia tersebut merupakan usia yang ideal untuk menikah dan hamil. Hasil tersebut sesuai dengan penelitian Prabowo et al. ${ }^{(8)}$ yang menunjukkan karakteristik usia yang mendominasi sebagai partisipan konseling adalah usia 21-30 tahun. Hal ini juga didukung oleh teori Soekanto ${ }^{(9)}$ bahwa semakin meningkatnya umur, maka tingkat kematangan dan kekuatan sesorang dalam berfikir dan bekerja akan lebih matang, sehingga seseorang akan semakin matang dalam berfikir serta memperoleh pengetahuan. Umur juga merupakan salah satu faktor yang menentukan perilaku seseorang termasuk dalam pemakaian alat kontrasepsi. ${ }^{(9)}$

Berdasarkan Tabel 1 juga terlihat bahwa jumlah responden tamatan SD sebesar 24 orang $(27 \%)$, tamatan SMP 30 orang

Tabel 4. Hubungan konseling antenatal, pengetahuan, sikap dan pilihan kontrasepsi

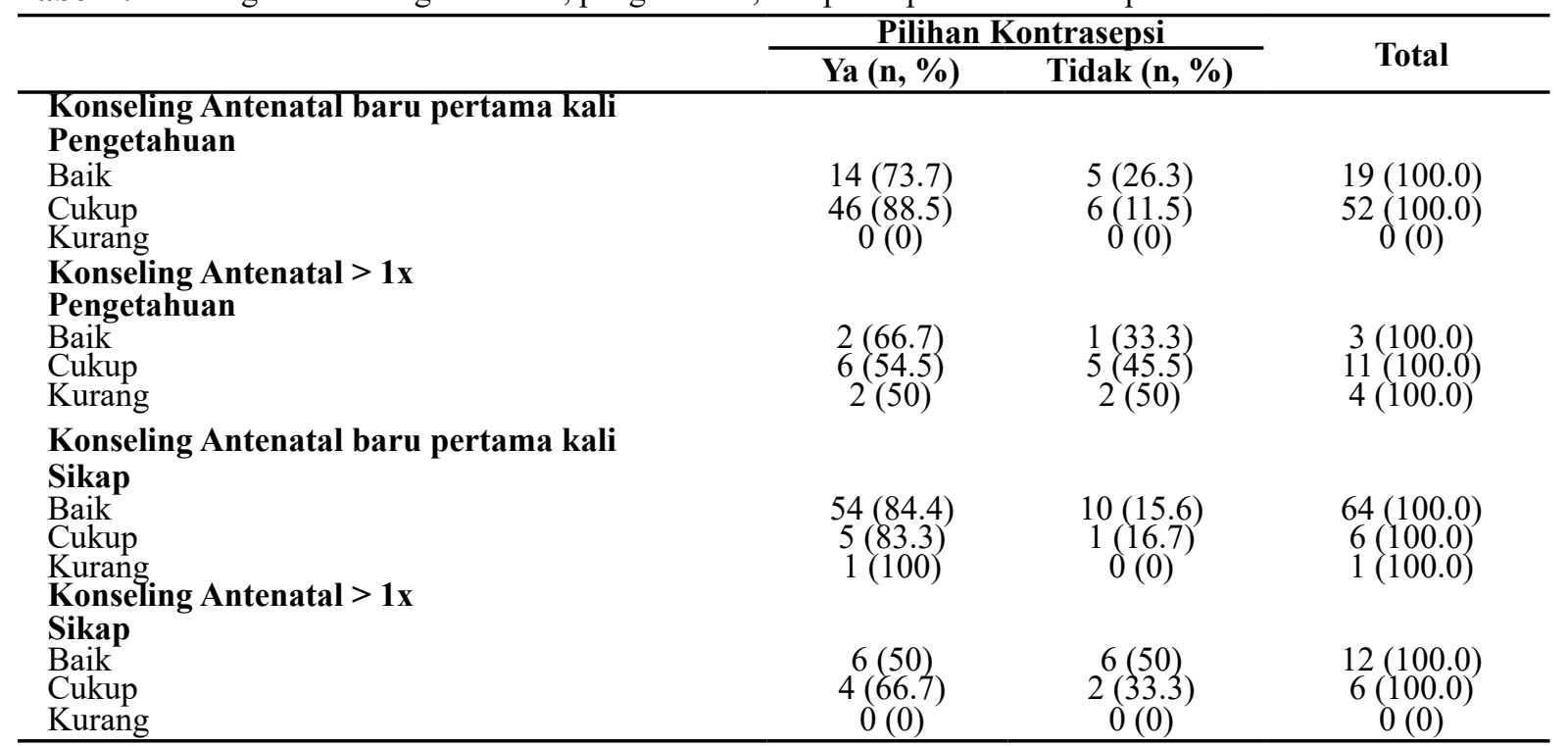


(33.7\%), tamatan SMA 30 orang (33.7\%) dan responden yang telah menempuh sarjana sebesar 5 orang $(5.6 \%)$. Hal ini didukung penelitian Sandrinilta et al. ${ }^{(10)}$ bahwa sebagian besar responden berpendidikan SMP. Hasil penelitian Kurnia et al. ${ }^{(11)}$ mendapatkan hasil responden terbanyak berpendidikan SMA. Purwaningsih et al. ${ }^{(12)}$ juga melaporkan hasil sebagian besar responden berpendidikan SMA/SMK. ${ }^{(10-12)}$ Notoatmodjo $^{(13)}$ menyatakan tingkat pendidikan akan memengaruhi daya serap responden terhadap informasi yang diterima. Semakin tinggi pendidikan seseorang maka pengetahuan akan semakin luas dan baik. ${ }^{(13)}$

Untuk kategori pekerjaan responden yang terbanyak adalah kelompok tidak bekerja sebanyak 71 orang (82.1\%) (Tabel 1). Hal ini sejalan dengan penelitian Darmawati ${ }^{(14)}$ yang menyatakan bahwa pekerjaan pada kelompok intervensi paling banyak pada kategori non pegawai. Responden dengan pengetahuan baik 22 orang $(24.7 \%)$, cukup 63 orang $(70.8 \%)$ dan kurang 4 orang $(4.5 \%)$. Hasil penelitian ini sesuai dengan penelitian Kurnia et al. ${ }^{(11)}$ yang menyatakan bahwa pengetahuan ibu hamil pada trimester III sebagian besar didominasi pengetahuan yang cukup.

Pengetahuan seseorang bisa dipengaruhi oleh latar belakang umur, pendidikan, pengalaman, paritas dan lingkungan dimana ia tinggal atau lingkungan yang dekat dengan aktifitasnya. Hal tersebut sesuai dengan teori yang dikemukakan Notoatmodjo ${ }^{(15)}$ bahwa seseorang yang lebih mudah menerima informasi maka akan memiliki pengetahuan yang baik. Pengetahuan cukup dicapai responden kemungkinan juga dipengaruhi umur, pendidikan dan paritas responden. Pengetahuan digunakan untuk menarik kesimpulan dari pengalaman seseorang. Pengetahuan terjadi setelah orang melakukan penginderaan terhadap suatu objek tertentu. Pengetahuan umumnya datang dari penginderaan yang terjadi melalui panca indera manusia. ${ }^{(15)}$

Tabel 2 memeprlihatkan jumlah responden yang memiliki sikap kategori baik 76 orang $(85.4 \%)$, kategori cukup 12 orang $(13.5 \%)$ dan kategori kurang 1 orang $(1.1 \%)$.
Hal ini bertentangan dengan penelitian Sulistyawati ${ }^{(16)}$ yang menyatakan bahwa sebagian besar responden mempunyai sikap kurang baik antara lain disebabkan karena tidak mendapat ijin dari suami. ${ }^{(16)}$ Responden yang memilih menggunakan alat kontrasepsi sebanyak 70 orang $(78.7 \%)$, sedangkan yang memilih tidak menggunakan alat kontrasepsi berjumlah 19 orang (21.3\%). Hal ini sesuai dengan penelitian Rahayu ${ }^{(17)}$ yang menyatakan 24 responden $(80 \%)$ berminat menggunakan KB setelah persalinan dan sebanyak 6 orang responden $(20 \%)$ menyatakan tidak berminat menggunakan $\mathrm{KB}$ pasca persalinan.

Konseling adalah proses pemberian informasi objektif dan lengkap dengan panduan keterampilan interpersonal, bertujuan mengenali kondisinya saat ini, masalah yang sedang dihadapi dan menentukan jalan keluar atau upaya untuk mengatasi masalah tersebut. Dengan melakukan konseling berarti petugas membantu klien dalam memilih dan memutuskan jenis kontrasepsi yang akan digunakan sesuai dengan pilihannya. ${ }^{(17)}$

Menurut Saifudin ${ }^{(18)}$ konseling merupakan aspek yang sangat penting dalam pelayanan Keluarga Berencana, yang merupakan proses yang berjalan menyatu dengan semua aspek pelayanan $\mathrm{KB}$ dan bukan hanya informasi yang diberikan dan dibicarakan pada satu kesempatan yakni pada saat pemberian pelayanan. Seringkali konseling diabaikan dan tidak dilaksanakan dengan baik karena petugas tidak mempunyai waktu dan tidak menyadari pentingnya konseling. ${ }^{(18)}$

Pada Tabel 3 yang menggambarkan hubungan konseling antenatal dengan pemilihan kontrasepsi, didapatkan $\mathrm{p}=0.020$. Maka dapat disimpulkan bahwa terdapat hubungan yang bermakna antara pilihan kontrasepsi dengan riwayat konseling. Hal ini sesuai dengan penelitian Sari SK, et al. ${ }^{(19)}$ terdapat hubungan bermakna antara konseling Keluarga Berencana (KB) dengan pengambilan keputusan Pasangan Usia Subur (PUS) dalam penggunaan alat kontrasepsi karena didapatkan hasil $\mathrm{p}=0.00$. Keputusan Penggunaan Alat Kontrasepsi merupakan suatu reaksi terhadap beberapa 
solusi alternatif yang dilakukan secara sadar dengan cara menganalisa kemungkinankemungkinan dari alternatif tersebut bersama konsekuensinya pada alat kontrasepsi. ${ }^{(19)} \mathrm{Hal}$ ini sejalan dengan penelitian yang dilakukan oleh Tanjung ${ }^{(20)}$ tentang hubungan pemberian konseling KB dengan pemilihan Alat Kontrasepsi IUD di Lingkungan II Kelurahan Sumber Jaya Kecamatan Siantar Martoba Pematang Siantar Sumatera Utara tahun 2010 yang menyebutkan bahwa konseling yang dilakukan oleh bidan mencapai 79\%.

Berdasarkan uraian di atas, terlihat bahwa konseling merupakan aspek yang sangat penting dalam pelayanan Keluarga Berencana (KB) dan Kesehatan Reproduksi (KR). ${ }^{(21)}$ Hal serupa sejalan dengan penelitian Puspita $^{(22)}$ menunjukkan bahwa responden yang mendapatkan konseling dengan baik akan cenderung memilih alat kontrasepsi dengan benar dan tepat. Pada akhirnya hal itu juga akan menurunkan tingkat kegagalan KB dan mencegah terjdinya kehamilan yang tidak diinginkan. Untuk meraih keberhasilan tersebut, tentunya sangat diperlukan tenagatenaga konselor yang profesional. Hasil penelitian Puspita ${ }^{(22)}$ menunjukkan bahwa responden yang mendapatkan konseling dengan baik akan cenderung memilih alat kontrasepsi dengan benar dan tepat. Pada akhirnya hal itu juga akan menurunkan tingkat kegagalan $\mathrm{KB}$ dan mencegah terjadinya kehamilan. ${ }^{(22)}$

Dari Tabel 3 juga terlihat setelah melakukan konseling terdapat responden yang tidak memilih untuk menggunakan alat kontrasepsi setelah melahirkan. Hal ini sejalan dengan penelitian Hanum $\mathrm{Z}$ et al. ${ }^{(23)}$ yang menyatakan bahwa akseptor $\mathrm{KB}$ yang mendapatkan konseling sebagian besar tidak berminat menggunakan alat kontrasepsi (seperti implant), disebabkan faktor lingkungan. Akseptor KB cenderung percaya dengan informasi yang di dapat dari lingkungan dibandingkan dengan informasi yang didapatkan dari tenaga kesehatan. Tidak hanya itu pengetahuan yang diperoleh responden dari konseling mengenai cara pemasangan membuat para akseptor KB merasakan khawatir dengan adanya proses pembedahan. Sehingga meskipun mereka mendapatkan konseling yang baik, faktor lingkungan menjadi lebih dominan sehingga akseptor tidak berminat untuk menggunakan implant. ${ }^{(23)}$

Keterbatasan penelitian ini adalah responden hanya diambil dari satu Puskesmas, jadi hasil penelitian belum bisa menjelaskan hubungan konseling antenatal dengan pengetahuan dan sikap pemilihan kontrasepsi ibu hamil primigravida secara umum. Penelitian hanya melihat pengetahuan dan sikap dari responden saja, belum melihat secara detail jenis alat kontrasepsi yang responden inginkan. Penelitian selanjutnya diharapkan, bisa menjelaskan variabel lain yang mempengaruhi pemilihan alat kontrasepsi seperti dukungna suami, keluarga, dan variabel lainnya. Untuk peneliti berikutnya dapat melakukan penelitian hubungan antara tingkat pendapatan dan pendidikan dengan keputusan pemilihan kontrasepsi pada Ibu hamil di Puskesmas Pasekan. Penelitian selanjutnya diharapkan, bisa menjelaskan variabel lain yang mempengaruhi pemilihan alat kontrasepsi seperti dukungan suami, keluarga, dan variabel lainnya.

\section{KESIMPULAN}

Dari hasil penelitian dapat disimpulkan bahwa terdapat hubungan antara konseling antenatal pada ibu hamil primigravida dengan pemilihan kontrasepsi setelah melahirkan. Sebagian besar responden yang melakukan konseling antenatal pertama kali dan mempunyai pengetahuan yang cukup dan mau menggunakan kontrasepsi sebanyak 46 orang $(88.5 \%)$. Sebagian besar responden yang melakukan konseling baru pertama kali adalah responden yang mempunyai sikap baik dan mau menggunakan kontrasepsi sebanyak 54 orang $(84.4 \%)$.

\section{KONTRIBUSI KEPENGARANGAN}

RWT menyusun konsep dan rancangan penelitian, pengumpulan data, analisis data, interpretasi data dan menyiapkan makalah. PSP menyusun rancangan penelitian, interpretasi data, revisi makalah akhir untuk publikasi. 


\section{DAFTAR REFERENSI}

1. Profil Kesehatan Indonesia. Jakarta: Kementerian Kesehatan Republik Indonesia; 2015.

2. Badan Pusat Statistik, Badan Koordinasi Keluarga Berencana Nasional, Departemen Kesehatan, Macro International. Survei Demografi dan Kesehatan Indonesia 2012. Jakarta: SDKI; 2014

3. Burhan L. Pengaruh Contraceptive Prevalence Rate (CPR) dan Total Fertility Rate (TFR) Terhadap Efektivitas Program KB dan Pemberdayaan Ekonomi Keluarga dan Peningkatan Kesejahteraan Keluarga Di Provinsi Nusa Tenggara Barat. J Ilmu Ekonomi Dan Manajemen. 2008;4:51-99.

4. Utami AH, Desmiwati, Endrinal. Faktor-faktor yang Berhubungan Dengan Unmet Need KB Pasca- Salin IUD post-placenta di Kamar Rawat Pasca-bersalin RSUP DR. M. Djamil periode Januari-Maret 2013. J Kes Andalas. 2013;2;159-61.

5. Ma Akman, St Üzün, Au Zuner, A Basgul and Z Kavak. The Influence Of Prenatal Counselling On Postpartum Contraceptive Choice. J Int Med Res. 2010;1:1243-49.

6. Jurisman A, Ariadi, Kurniati R. Hubungan Karakteristik Ibu dengan Pemilihan Kontrasepsi di Puskesmas Padang Pasir Padang. J Kes Andalas. 2016;5:191-5.

7. Danish N, Fawad A, Abbasi N. Assessment Of Pregnancy Outcome In Primigravida: Comparison Between Booked And Un-Booked Patients. J Ayub Med Coll Abbottabad. 2010;22:23-5.

8. Prabowo A, Sari. Hubungan pengetahuan dan sikap pria tentang keluarga berencana dengan perilaku pria dalam berpartisipasi menggunakan metode kontrasepsi keluarga berencana di desa Larangan kecamatan Larangan kabupaten Brebes. Jurnal Gaster. 2011;8:633-46.

9. Soekanto S. Sosiologi suatu pengantar. Jakarta: Raja Grafika Persada; 2007. 128 p.

10. Sandrinilta, Isnaneni Y. Hubungan pemberian konseling pada akseptor KB terhadap ketepatan pemilihan alat kontrasepsi di Puskesmas Tegalrejo [Skripsi]. [Yogyakarta]: Universitas 'Aisyiyah Yogyakarta; 2015.

11. Kurnia N, Paraatmadja Y, Maharani O. Pengetahuan ibu hamil trimester III tentang KB pasca persalinan di Puskesmas Jetis kota, Yogyakarta. JNKI. 2015;3:16-22

12. Purwaningsih E, Zuhri S, Rachmawati A. Pengaruh pemberian konseling terhadap pengetahuan dan minat pengguna kontrasepsi mal di ponet grobongan Jawa Tengah. Jurnal involusi Kebidanan. 2016;6:6-12

13. Notoatmodjo, S. Metodologi penelitian kesehatan. Jakarta: Rineka Cipta; 2010. 1-5 p.

14. Darmawati. Pengaruh efektifitas konseling terhadap dukungan suami dalam pengambilan keputusan $\mathrm{KB}$ dan pemilihan kontrasepsi. Idea Nursing J. 2011.3:24-8.

15. Notoatmodjo S. Promosi kesehatan dan ilmu perilaku. Jakarta: Rineka Cipta; 2007. 145 p.

16. Sulistyawati, Ari. Pelayanan Keluarga Berencana. Jakarta: Salemba Medika; 2011.

17. Rahayu EW, Rusminingsih. Pengaruh konseling keluarga berencana terhadap tingkat pengetahuan dan minat menjadi akseptor KB pasca persalinan di Puskesmas Mlati II Yogyakarta. [Skripsi]. [Yogyakarta]: Universitas 'Aisyiyah Yogyakarta; 2015 .
18. Saifuddin. Buku Panduan Praktis Pelayanan Kontrasepsi. Jakarta: Yayasan Bina Pustaka Sarwono Prawirohardjo; 2007.

19. Sari SK, Suryani EV, Handayani R. Hubungan konseling keluarga berencana (KB) dengan pengambilan keputusan pasangan usia subur (pus) dalam penggunaan alat kontrasepsi. Bidan Prada: J Ilmiah Kebidanan. 2010:1(1);37-47.

20. Tanjung. Hubungan Pemberian konseling KB dengan Pemilihan Alat Kontrasepsi IUD di Lingkungan II Kelurahan Sumber Jaya Kecamatan Siantar Martoba Pematang Siantar Sumatera Utara tahun 2010. [Karya Tulis Ilmiah]. [Medan]: 2010

21. Sarwono. Fisiologi dan Patologi Persalinan (terjemahan). Jakarta: Yayasan Bina Pustaka Sarwono Prawirohardjo; 2003.

22. Puspita. Hubungan Antara Pemberian Konseling Dengan Pemilihan Alat Kontrasepsi Pil di Wilayah Puskesmas Kuala Lempuing Kota Bengkulu. [Karya Tulis Ilmiah]. Jakarta: Pustaka; 2010.

23. Hanum Z, Saputri I. Konseling dan Dukungan Suami Dengan Minat Ibu Dalam Pemakaian Kontrasepsi Implan. Lentera. 2014:14;1-5. 